\title{
Cell Dehydration as a Mechanism of Ketamine Analgesic and Anesthetic Effects
}

\author{
Sinerik Ayrapetyan*, Armenuhi Heqimyan and Anush Deghoyan
}

Life Sciences International Postgraduate Educational Center, 31 Acharyan St. 0040 Yerevan, Armenia

\begin{abstract}
Effect of intraperitoneally (i.p.) injected sub-anesthetic $\left(8 \times 10^{-5}-8 \times 10^{-2} \mathrm{mg} / \mathrm{g}\right)$ and anesthetic $(0.1 \mathrm{mg} / \mathrm{g})$ doses of ketamine on rats' pain sensitivity and tissue hydration were studied. Determination of water content of tissue was performed by Adrian's traditional "tissue drying" experimental procedure. The number of functionally active receptors were determined by counting the number of $\left[{ }^{3} \mathrm{H}\right]$-ouabain molecules in tissues. Latent period of pain sensitivity was defined by means of hot plate test. Ketamine in sub-anesthetic doses had depressing effect on rats' latent period of pain sensitivity which was accompanied by tissues' dehydration. $\left[{ }^{3} \mathrm{H}\right]$-ouabain influence on brain tissues hydration was characterized by dose dependent three phases and this fact was accompanied by corresponding changes of ouabain receptors number in cell membrane. Ketamine in anesthetic dose had reversing effect on ouabain - induced cell hydration and it was different for each brain tissue. It was suggested that ketamine - induced cell dehydration leading to decrease of number of functional active proteins in membrane serves as a powerful mechanism through which an analgesic and anesthetic effects of ketamine on organisms were realized.
\end{abstract}

Keywords: Rat; ketamine; $\left[{ }^{3} \mathrm{H}\right]$-ouabain receptor; Pain sensitivity; Cell hydration

\section{Introduction}

It is assumed that ketamine administration causes "dissociative anesthetic state" characterized by profound analgesic, moderate hypnotic properties and by marked sympathomimetic reactions.

Its pharmacological profile cannot be explained by a single mechanism. Analgesic, anesthetic and sympathomimetic effects are mediated by different sides of action. It is suggested that N-methyl$\mathrm{D}$-aspartate (NMDA)-receptor antagonism accounts for most of the amnestic, analgesic, psychotomimetic and neuroprotective effects of ketamine [1,2]. Ketamine blocks an NMDA receptor-mediated component of synaptic transmission in a voltage-dependent manner [3-7].

The ketamine depressing effect on variety of receptors is well established: nicotinic [8,9], muscarinic [10] and opioid ones [10-12], as well as on voltage sensitive $\mathrm{Na}^{+}[9,13], \mathrm{K}^{+}[13-15]$ and $\mathrm{Ca}^{2+}$ channels [16] of nerve cell membrane in peripheral and central nervous system. At present it is known that ketamine influence is not limited only by nervous system but it has also relaxing effect on smooth and heart muscles [17-20] and other tissues [21]. However, the nature of cellular mechanism underlying in the ground of above mentioned multisided effects of ketamine on different tissues is not clear yet.

Earlier on the basis of experimental data performed in vitro on snail single neurons the correlation between the number of functionally active membrane receptors having channel [22], receptor [23], enzyme functions [24] and active cell membrane surface was established. According to these data cell swelling leads to the activation, while shrinkage to the inhibition of neurons' functional activity. Therefore, the metabolic control of cell volume-induced changes of membrane functional activity was suggested as an essential mechanism through which the regulation of neuronal ionic function is realized [25].

It is known that there are a number of non-conductive membrane mechanisms responsible for cell volume regulation such as $\mathrm{Na}^{+} /$ $\mathrm{K}^{+}$pump, $\mathrm{Na}^{+} / \mathrm{Ca}^{++}, \mathrm{Na}^{+} / \mathrm{H}^{+}$exchangers, changes of cytoskeleton contractility and membrane fluidity and others [26]. Previously in vitro experiments (on snail neurons and women breast tissue) ketamine stimulating effect on $\mathrm{Na}^{+} / \mathrm{K}^{+}$pump and $\mathrm{Na}^{+} / \mathrm{Ca}^{++}$exchanger has been shown which brings to cell dehydration [27-29].

Therefore, the working hypothesis for present work was to clarify whether the ketamine- induced cell volume change has a crucial role in realization of analgesic and anesthetic effects as well as its multisided effect on different organs. For this purpose the dose-dependent effect of ketamine on rats' pain sensitivity, hydration of different organs' tissues and the number of $\left[{ }^{3} \mathrm{H}\right]$-ouabain receptors were studied.

\section{Materials and Methods}

All procedures performed on animals were carried out following the protocols approved by Animal Care and Use Committee of Life Sciences Postgraduate International Educational Center.

\section{Animals}

All experiments were performed on 180 adult male albino rats weighing from $100 \mathrm{~g}$ to $130 \mathrm{~g}$. Animals were kept in a specific pathogenfree animal room, under optimum conditions of 12 hours light/dark cycle and $22 \pm 2^{\circ} \mathrm{C}$ temperature, received sterilized commercial diet and water ad libitum. Data were received from three independent experiments.

For controlgroup 5 animals were taken and injected intraperitoneally (i.p.) by $0.5 \mathrm{ml}$ of physiological saline (PS). Five animal groups ( 5 rats in each) were used for each ketamine concentration injected by the same manner.

*Corresponding author: Sinerik Ayrapetyan, UNESCO Chair-Life Sciences International Postgraduate Educational Center, 31 Acharyan St. 0040 Yerevan, Armenia, Tel: +374 10 624170; Fax: +374 10 624170; E-mail: info@biophys.am

Received March 01, 2013; Accepted April 18, 2013; Published April 25, 2013

Citation: Ayrapetyan S, Heqimyan A, Deghoyan A (2013) Cell Dehydration as a Mechanism of Ketamine Analgesic and Anesthetic Effects. J Bioequiv Availab 5: 136-141. doi:10.4172/jbb.1000148

Copyright: (c) 2013 Ayrapetyan S, et al. This is an open-access article distributed under the terms of the Creative Commons Attribution License, which permits unrestricted use, distribution, and reproduction in any medium, provided the original author and source are credited. 


\section{Chemicals}

Physiological solution (PS) with $\mathrm{NaCl}-137 ; \mathrm{KCl}-5.4 ; \mathrm{CaCl}_{2}-1.8$; $\mathrm{MgCl}_{2}-1.05 ; \mathrm{C}_{6} \mathrm{H}_{12} \mathrm{O}_{6}-5 ; \mathrm{NaHCO}_{3}-11.9 ; \mathrm{NaH}_{2} \mathrm{PO}_{4}-0.42$ in $\mathrm{mM}$ (Sigma Chemicals, Steinhein, Germany) and $\mathrm{pH}-7.4$ was used in all experiments. The stock solution of ketamine containing $500 \mathrm{mg}$ ketamine solved in $10 \mathrm{ml}$ of PS was used (Gedeon Richter, Budapest, Hungary). Ketamine anesthetic $(0.125 \mathrm{mg} / \mathrm{g})$ and subanesthetic $\left(8 \times 10^{-5}-8 \times 10^{-2} \mathrm{mg} / \mathrm{g}\right)$ doses were injected intraperitoneally (i.p.). The $\left[{ }^{3} \mathrm{H}\right]$-ouabain (PerkinElmer, Massachusetts, USA) with $10^{-11}-10^{-4} \mathrm{M}$ concentrations were taken as a marker for definition of tissue volume changes and injected i.p. According to animal's body weight $(0.02 \mathrm{ml} / \mathrm{g})$.

\section{Tissue preparation}

Tissues of different organs (lungs, heart, spleen, liver, kidney, muscle and brain) were investigated on 75 animals of control and experimental groups (at ketamine different doses). For definition the tissue water content and the number of ouabain receptors (ten pieces from each organ tissue, weighing from 50 to $60 \mathrm{mg}$ ) were taken from each rat. From cortex and subcortex tissues of brain eight pieces were taken while from cerebellum tissue only four pieces for every case.

\section{Definition of tissues water content}

After 15 min of PS, ketamine and [3H]-ouabain injections animals were sharply immobilized by dipping their noses into liquid nitrogen for 3-4 sec [30] and were decapitated. After such procedure the full absence of somatic reflexes on extra stimuli was recorded.

Determination of water content of tissue was performed by traditional "tissue drying" method [Adrian 31]. After measuring the tissue wet weight (w.w.) it was dried in thermostat (Factory of Medical Equipment, Odessa, Ukraine) during 24 hours at $105^{\circ} \mathrm{C}$ for determination of dry weight (d. w.). The quantity of water in $1 \mathrm{~g}$ of d.w. of tissue was counted by the following equation: (w.w. - d.w.) / d.w. [31].

\section{Counting the number of ouabain receptors in cell membrane}

For definition of membrane active receptors' number 15 animals injected with $\left[{ }^{3} \mathrm{H}\right]$-ouabain (3 animals for each $\left[{ }^{3} \mathrm{H}\right]$-ouabain dose) were taken for control group and 15 animals ( 3 animals for each $\left[{ }^{3} \mathrm{H}\right]$ ouabain dose and sequential ketamine anesthetic dose injections) for experimental one. Animals of control group were decapitated $30 \mathrm{~min}$ after corresponding $\left[{ }^{3} \mathrm{H}\right]$-ouabain injection. Animals of experimental group $15 \mathrm{~min}$ after $\left[{ }^{3} \mathrm{H}\right]$-ouabain corresponding dose injection received ketamine anesthetic dose and were decapitated $15 \mathrm{~min}$ after. The stock of $\left[{ }^{3} \mathrm{H}\right]$-ouabain solution contains $10^{-9} \mathrm{M}$ concentration (12 $\mathrm{Ci} / \mathrm{mM}$ specific activities). The solutions with $\left[{ }^{3} \mathrm{H}\right]$-ouabain higher concentrations $\left(10^{-8}-10^{-4} \mathrm{M}\right)$ were prepared by adding corresponding concentration of cold (non-labeled) ouabain.

Brain tissues' samples were placed in special vials and homogenized with $\mathrm{HNO}_{3}$. Finally, $5 \mathrm{ml}$ of Bray's scintillation fluid was added and the mixture was counted in Wallac-1450 liquid scintillation counter (PerkinElmer, Finland). After this procedure the amount of scintillate isotopes counted per minute was received and correspondingly calculated as the number of ouabain receptors.

\section{Determination of pain sensitivity latent period}

This test was carried out using the specific setup developed in our laboratory. It consists of org-glass chamber with the brass bottom. The bottom temperature $\left(51^{\circ} \mathrm{C}\right)$ was controlled by the thermometer (accuracy of measurement $0.01^{\circ} \mathrm{C}$ ). Brass bottom was completely covered by the Plexiglas box keeping the temperature constant.

Latent period of pain sensitivity was recorded 15 min after PS or ketamine subanesthetic doses injections. This procedure was made consequently, every time only on one animal. Rats were placed individually on brass bottom and latent period of pain sensitivity was recorded as the time elapsed to obtain one of the following responses: licking the feet, jumping or rapidly stamping the feet. The tissue damage prevention was near $10 \mathrm{sec}$. Decapitation was made just after the measurement of latent period. Statistic significance was defined between data of control and experimental groups.

\section{Statistical analysis}

The Microsoft Excel and Sigma-Plot (Version 8.02A) were used for data analysis. For all statistical tests (with Student's t-test) $\mathrm{P}$ value of 0.05 or less was taken $\left({ }^{\star} \mathrm{P}<0.05,{ }^{*} \mathrm{P}<0.01,{ }^{* *} \mathrm{P}<0.001\right)$.

\section{Results}

In the first part of experiments the effect of PS and ketamine subanesthetic doses on latent period of pain sensitivity was investigated. After this procedure animals were decapitated and water content in various organs was measured. In figure 1 the bars indicate the value of latent period of pain sensitivity in five groups of animals. After i.p. ketamine injections the increase of latent period of pain sensitivity more than three times $\left(8 \times 10^{-4}-8 \times 10^{-2} \mathrm{mg} / \mathrm{g}\right)$ was shown and it's threshold concentration was $8 \times 10^{-5} \mathrm{mg} / \mathrm{g}$.

Recently in our experiments the close correlation between brain tissue hydration and pain sensitivity has been demonstrated [32]. In previous groups of animals after determination of latent period water content in rats' tissues was examined. Ketamine was taken i.p. in subanesthetic $\left(8 \times 10^{-4}-8 \times 10^{-2} \mathrm{mg} / \mathrm{g}\right)$ and anesthetic $(0.125 \mathrm{mg} / \mathrm{g})$ doses. In figure 2 dose-dependent effect of ketamine on water content of brain tissues is shown. As can be seen from figure the curve of ketamine dose-dependent effect on cortex tissue hydration is different from those of subcortex and cerebellum. Ketamine at following concentrations $\left(8 \times 10^{-4}-8 \times 10^{-3} \mathrm{mg} / \mathrm{g}\right)$ has no significant effect on all brain tissues hydration, while at $8 \times 10^{-2} \mathrm{mg} / \mathrm{g}$ it has strong dehydration effect (decrease of water content) on all types of tissues. Ketamine at

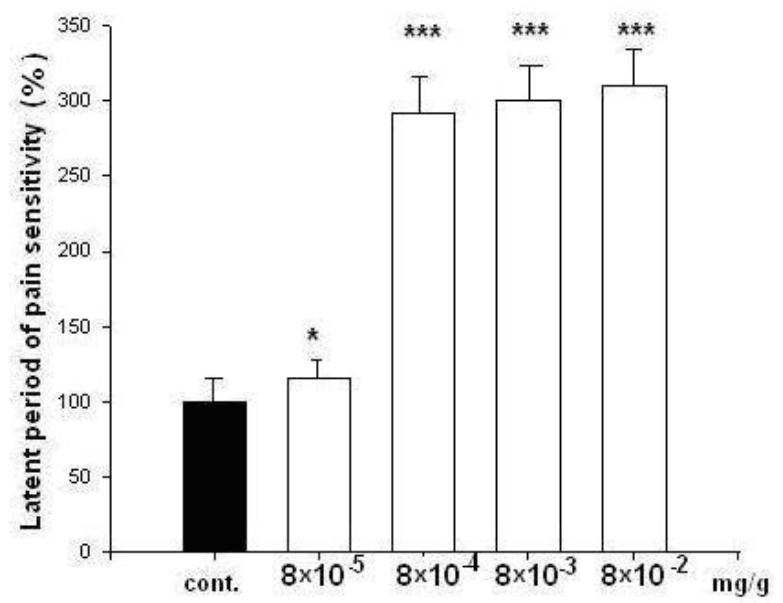

Figure 1: The value of latent period of pain sensitivity in five groups of animals. 
concentration of $0.125 \mathrm{mg} / \mathrm{g}$ (which had anesthetic effect on rats) shows overhydration effect (increase in water content) on cortex tissue (Figure 2a) and dehydration effect on subcortex and cerebellum tissues (Figures $2 \mathrm{~b}$ and $2 \mathrm{c}$ ). The fact that ketamine at anesthetic dose brings to the overhydration of cortex tissue corresponds to the data where the exciting effect of ketamine on brain cortex is explained by its stimulation of some groups of glutamate receptors [33].

The study of the dose-dependent effect of ketamine was also carried out on tissues of other organs (lung, heart, spleen, liver, kidney and muscle) to find out whether observed tissue hydration conditioned by ketamine is a general property or it is only specific for brain tissues. In figure 3 changes of tissues' ketamine-dependent water content at different doses are shown. As can be seen from figure at the smallest dose $\left(8 \times 10^{-4} \mathrm{mg} / \mathrm{g}\right)$ of ketamine there is an overhydration effect in all tissues except the spleen tissue (small, no significant dehydration effect). At ketamine $8 \times 10^{-3} \mathrm{mg} / \mathrm{g}$ dose in all investigated tissues dehydration effect was observed but in muscle tissue significant overhydration effect was revealed. The dehydration effect in lung, heart, spleen, kidney tissues were also found at higher doses of ketamine $\left(8 \times 10^{-2} \mathrm{mg} / \mathrm{g}\right.$ i.p. $)$ but in the case of liver and muscle tissues the opposite one (overhydration effect). In the last group of animals when the anesthetic dose of ketamine $(0.125 \mathrm{mg} / \mathrm{g}$ i.p.) was injected the dehydration effect on tissues of all organs except liver was observed. Thus, the presented data indicate

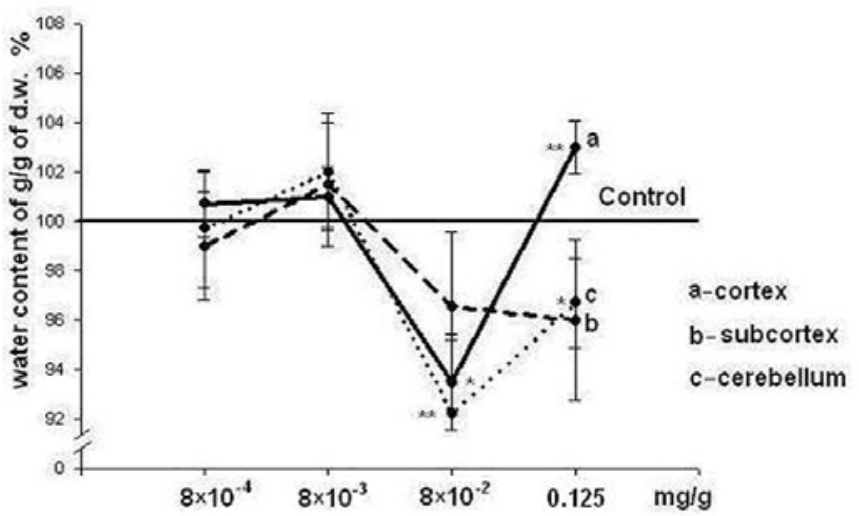

Figure 2: Dose-dependent effect of ketamine on water content of brain tissues.animals.

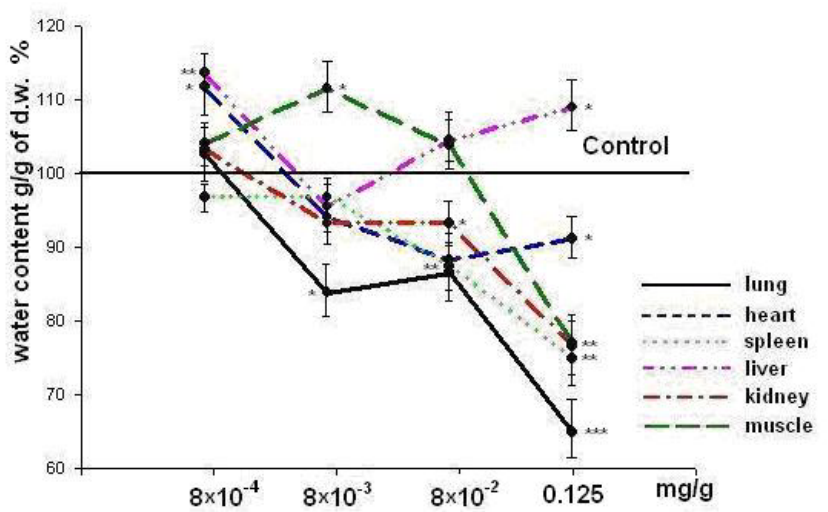

Figure 3: Changes of tissues' ketamine-dependent water content at different doses. that ketamine has modulating effect on tissue hydration of different organs and its sensitivity to ketamine is different which can be probably explained by special mechanisms involved in cell volume regulation or various quantity of ketamine reaching these cells by blood flow.

Previously it has been shown that cell volume control is connected with $\mathrm{Na}^{+} / \mathrm{K}^{+}$pump [24], cGMP-dependent [34] and cAMP-dependent $\mathrm{Na}^{+} / \mathrm{Ca}^{++}$exchangers' activities [35]. In these studies by means of $\left[{ }^{3} \mathrm{H}\right]-$ ouabain (specific inhibitor of $\mathrm{Na}^{+} / \mathrm{K}^{+}$ATP-ase) cell volume changes were defined. $\left[{ }^{3} \mathrm{H}\right]$-ouabain binds to membrane $\mathrm{Na}^{+} / \mathrm{K}^{+}$ATP-ase receptors. Kinetic curve of dose-dependent $\left[{ }^{3} \mathrm{H}\right]$-ouabain binding with neuronal membrane functionally active proteins consisted of two saturated and one linear component. It turned out that only the last component of curve was connected with $\mathrm{Na}^{+} / \mathrm{K}^{+}$pump activity [21] From this point of view in the last series of experiments the possible mechanism of ketamine anesthetic dose $(0.125 \mathrm{mg} / \mathrm{g})$ and influence on dose-dependent ouabain-induced cell hydration in brain tissues (cortex, subcortex, cerebellum) were studied for finding out whether this process is accompanied by corresponding change of membrane functionally active proteins' number. For this reason $\left[{ }^{3} \mathrm{H}\right]$-ouabain was taken as a marker for determination of membrane functionally active proteins.

In figure 4 points on continuous line mean values of water content in brain tissues are shown and the kinetic curve of dose-dependent ouabain effects is formed by three ranges. For ouabain $10^{-9}-10^{-8} \mathrm{M}$ concentrations overhydration process is detected, at $10^{-7}-10^{-6} \mathrm{M}$ dosedehydration effect and at $10^{-4} \mathrm{M}$ doses again overhydration process is received. These changes of water content are the same for all investigated tissues.

In parallel experiments carried out on the next 5 animal groups $(n=3)$, where the same $[3 \mathrm{H}]$-ouabain concentrations were injected and $15 \mathrm{~min}$ after this procedure the ketamine anesthetic dose $(0.125 \mathrm{mg} / \mathrm{g})$ was injected. Animals were decapitated $15 \mathrm{~min}$ after. The comparison between two kinetic curves shows the following changes in cortex tissue (Figure 4A). After $10^{-9} \mathrm{M}$ of ouabain injection ketamine brings to the same overhydration effect. Ketamine-induced cell dehydration become more expressive after $10^{-8}$ and $10^{-7} \mathrm{M}$ ouabain injections. Then, it can be noted that $10^{-6} \mathrm{M}$ ouabain dehydration reverses into overhydration and overhydration at 10-4 $\mathrm{M}$ ouabain into dehydration. As for subcortex tissue it can be seen in figure $4 \mathrm{~B}$ that after $10^{-8}-10^{-4} \mathrm{M}$ ketamine injections meaningful dehydration effect is observed and dotted line having same three ranges is quite parallel to continuous one. In cerebellum tissue (after $10^{-9} \mathrm{M}$ ouabain injection) ketamine leads to overhydration effect more expressive than at ouabain influence (Figure 4C). At $10^{-8}-10^{-7} \mathrm{M}$ ouabain injection ketamine shows the same dehydration effect as in case of cortex tissue. $10^{-6} \mathrm{M}$ ouabain dehydration effect reverses into overhydration one after ketamine influence and overhydration (at $10^{-4}$ $\mathrm{M}$ of ouabain) to dehydration effect after ketamine injection. In table 1 was shown that at ouabain $10^{-8}-10^{-7} \mathrm{M}$ there is the close correlation between water content and number of membrane ouabain receptors.

\section{Discussion}

The investigation of ketamine influence on rats' pain sensitivity latent period, tissue hydration and number of ouabain receptors showed that its subanesthetic doses $\left(8 \times 10^{-5}-8 \times 10^{-2} \mathrm{mg} / \mathrm{g}\right)$ have statistically significant depressing effect on rats' pain sensitivity. The analgesic effect of these ketamine doses on mammals was commonly explained by its non-competitive inhibitory effect on NMDA receptors in brain [3-7]. However, ketamine effects on tissue hydration of various 

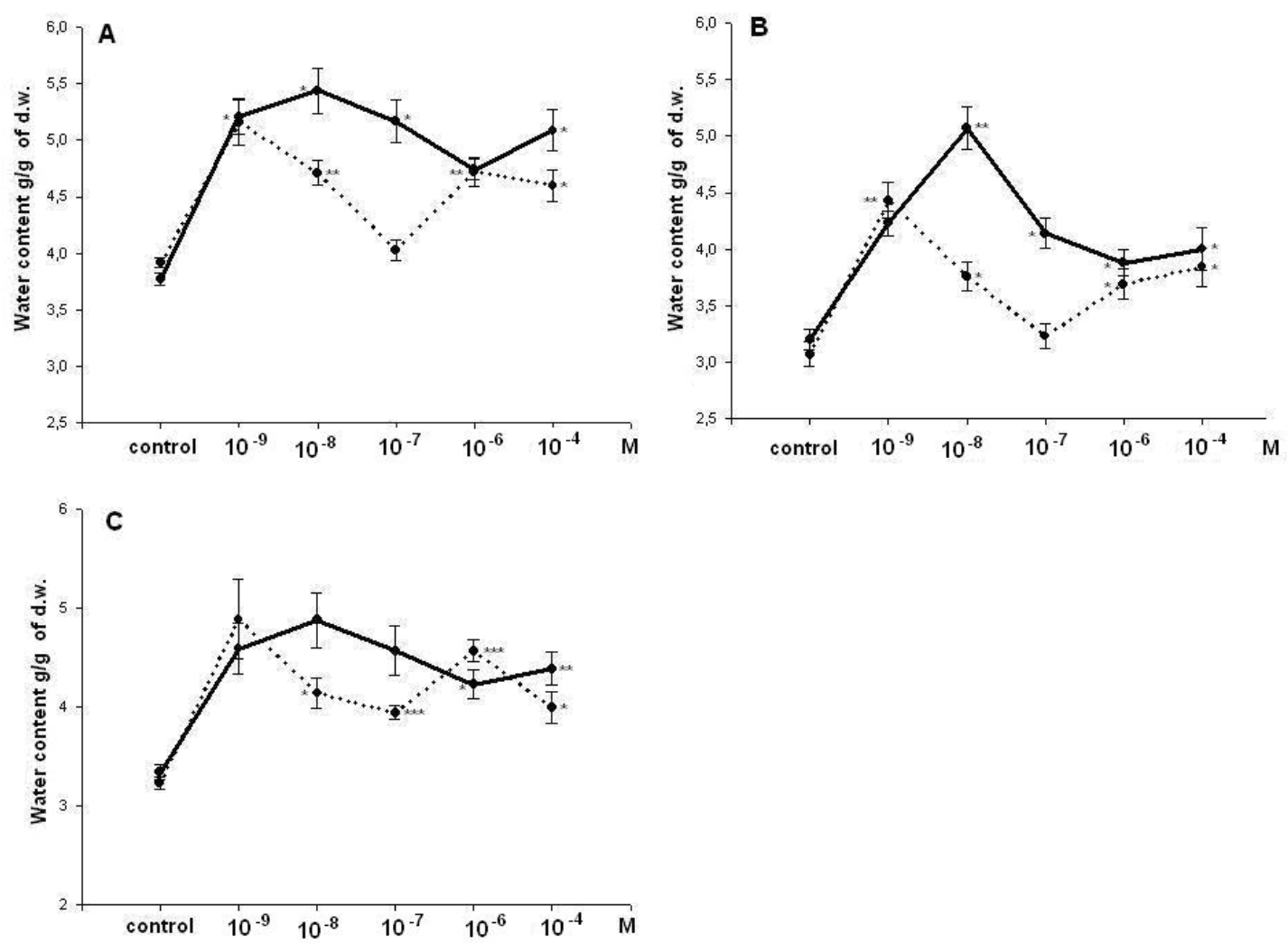

Figure 4: Continuous line mean values of water content in brain tissues.

\begin{tabular}{|c|c|c|c|c|c|}
\hline \multicolumn{6}{|c|}{ The number of $[3 \mathrm{H}]$-ouabain receptors $\times 10^{8}$} \\
\hline \multicolumn{6}{|c|}{ CORTEX } \\
\hline & $10^{-9} \mathrm{M}$ & $10^{-8} \mathrm{M}$ & $10^{-7} \mathrm{M}$ & $10^{-6} \mathrm{M}$ & $10^{-4} \mathrm{M}$ \\
\hline Control & $0.62 \pm 0.05$ & $1.58 \pm 0.07$ & $2.58 \pm 0.02$ & $3.08 \pm 0.19$ & $5.51 \pm 0.05$ \\
\hline Experiment & $0.69 \pm 0.03$ & $1.5 \pm 0.02$ & $2.33 \pm 0.03$ & $3.38 \pm 0.15$ & $5.52 \pm 0.03$ \\
\hline \multicolumn{6}{|c|}{ SUBCORTEX } \\
\hline & $10^{-9} \mathrm{M}$ & $10^{-8} \mathrm{M}$ & $10^{-7} \mathrm{M}$ & $10^{-6} \mathrm{M}$ & $10^{-4} \mathrm{M}$ \\
\hline Control & $0.63 \pm 0.03$ & $1.63 \pm 0.05$ & $2.54 \pm 0.02$ & $3.33 \pm 0.14$ & $5.49 \pm 0.04$ \\
\hline Experiment & $0.64 \pm 0.04$ & $1.48 \pm 0.02$ & $2.38 \pm 0.02$ & $3.27 \pm 0.14$ & $5.49 \pm 0.04$ \\
\hline \multicolumn{6}{|c|}{ CEREBELLUM } \\
\hline & $10^{-9} \mathrm{M}$ & $10^{-8} \mathrm{M}$ & $10^{-7} \mathrm{M}$ & $10^{-6} \mathrm{M}$ & $10^{-4} \mathrm{M}$ \\
\hline Control & $0.48 \pm 0.08$ & $1.58 \pm 0.08$ & $2.65 \pm 0.05$ & $3.48 \pm 0.05$ & $5.43 \pm 0.07$ \\
\hline Experiment & $0.67 \pm 0.05$ & $1.46 \pm 0.03$ & $2.44 \pm 0.04$ & $3.18 \pm 0.32$ & $5.59 \pm 0.07$ \\
\hline
\end{tabular}

Table 1: Correlation between water content and number of membrane ouabain receptors.

organs (lung, heart, spleen, liver, kidney and skeletal muscle) indicated that its effect was connected not only with neuronal membrane conductive functions. This conclusion is conformed to our previous data of ketamine induced dehydration effect on women breast tissue [28].

At present it is a proven fact that metabolic control of cell volume is a dynamic cell parameter through which the regulation of cell various functions is realized $[25,26,36,37]$. Non-linear curves of dose- dependent ketamine effect on tissue hydration in brain and different organs could be explained by multisided effects of ketamine on mechanisms involved in cell volume regulation.

Although there is a number of metabolic mechanisms involved in cell volume regulation the electrogenic ionic transporting mechanisms such as $\mathrm{Na}^{+/} \mathrm{K}^{+}$pump and $\mathrm{Na}^{+} / \mathrm{Ca}^{++}$exchanger have a crucial role in this process [38-40]. Earlier it was shown that ketamine has activation effect on electrogenic $\mathrm{Na}^{+} \mathrm{K}^{+}$pump and $\mathrm{Na}^{+} / \mathrm{Ca}^{++}$exchanger activity in 
isolated neurons of mollusc through which it causes cell dehydration and decrease in membrane fluidity $[24,41]$.

In the study of dose-dependent ouabain binding with neuronal membrane three types of ouabain receptors was distinguished [24]. Among them the function of only one-dose dependent linear binding having low agonist affinity is connected with $\mathrm{Na}^{+} / \mathrm{K}^{+}$pump inhibition, while the functions of two types of receptors having higher agonist affinity and characterized by dose-dependent saturated curves are connected with cGMP-dependent $\mathrm{Na}^{+} / \mathrm{Ca}^{++}$and cAMP-dependent $\mathrm{Na}^{+} / \mathrm{Ca}^{++}$exchangers' mechanisms, correspondingly [24,34,35]. As these ion transporting mechanisms are electrogenic, they can modulate the level of cell hydration: activation of cGMP-dependent $\mathrm{Na}^{+} / \mathrm{Ca}^{++}$ exchanger and inactivation of $\mathrm{Na}^{+} / \mathrm{K}^{+}$pump brings to cell swelling, while activation of cAMP-dependent $\mathrm{Na}^{+} / \mathrm{Ca}^{++}$exchanger brings to cell shrinkage.

Considering the curves of dose-dependent ouabain-induced tissue hydration (Figure 4), three phases of ouabain- induced changes on tissue hydration can be clearly seen: overhydration at $10^{-9}-10^{-8} \mathrm{M}$, dehydration at $10^{-7}-10^{-6} \mathrm{M}$ and overhydration at $10^{-4} \mathrm{M}$. The fact that the ketamine has reverse effects on all the three components of ouabaininduced hydration, brings to conclusion that above mentioned ouabain receptors' function which is connected with cGMP-dependent $\mathrm{Na}^{+} /$ $\mathrm{Ca}^{++}$, cAMP-dependent $\mathrm{Na}^{+} / \mathrm{Ca}^{++}$exchangers and $\mathrm{Na}^{+} / \mathrm{K}^{+}$pump activity is ketamine sensitive. This conclusion confirms the previous isotope study of ketamine effects on $\mathrm{Na}^{+} / \mathrm{K}^{+}$pump activity and $\mathrm{Na}^{+} /$ $\mathrm{Ca}^{++}$exchanger in snail neurons according to which ketamine has activation effect on $\mathrm{Na}^{+} / \mathrm{Ca}^{++}\left(\mathrm{Ca}^{++}\right.$efflux $\mathrm{Na}^{+}$influx) exchange and $\mathrm{Na}^{+} / \mathrm{K}^{+}$pump activity [24].

The fact that ketamine has slight hydration effect on brain tissues which was accompanied by increased number of ouabain receptors at $10^{-9} \mathrm{M}$ ouabain concentration (Table 1) can be explained by the activation of cGMP-dependent $\mathrm{Na}^{+} / \mathrm{Ca}^{++}$exchanger which is responsible for cell hydration as it was mentioned above.

The fact that non-anesthetic dose $\left(8 \times 10^{-2} \mathrm{mg} / \mathrm{g}\right.$ i.p. $)$ of ketamine has dehydration effect on brain tissues which is accompanied by corresponding decrease in number of ouabain receptors at $10^{-8}-10^{-7}$ $\mathrm{M}$ ouabain concentrations (Table 1), can be explained by activation of cAMP-dependent $\mathrm{Na}^{+} / \mathrm{Ca}^{++}$exchanger $\left(\mathrm{Ca}^{++}\right.$influx and $3 \mathrm{Na}^{+}$efflux $)$ responsible for cell dehydration [34,35].

Thus, the above mentioned results and literature data about involvement of intracellular cyclic nucleotides in brain psychological processes [42] lead to the hypothesis that hallucination effect of ketamine is connected with its modulation effect on cyclic nucleotides metabolism which could serve as a subject for the future investigation.

The data of close correlation between cell hydration and the number of functionally active protein molecules determining the cell functional activity [25] and recent data on direct correlation between brain tissue hydration and rats pain sensitivity [32] allow to consider ketamine dehydration effect at sub-anesthetic doses as an essential mechanism responsible for its depression effect on pain sensitivity of rats. On the basis of the fact that ketamine anesthetic dose has only dehydration effect on subcortex and cerebellum tissue and overhydration effect on cortex tissue the suggestion can be made according to which anesthetic effect of ketamine is only responsible for subcortex and cerebellum tissues. This conclusion can not be final as it needs further investigation.

\section{Conclusion}

Obtained data allow us to confirm that analgesic effect of subanesthetic dose of ketamine can be explained by brain tissue dehydration. Dehydration effect on tissues of subcortex and cerebellum has essential role in realization of ketamine anesthetic effect on organism. Ketamine-induced cell volume changes accompanied by corresponding changes of number of functionally active proteins on cell membrane serve as one of the main non-conductive membrane mechanisms through which the biological effect of ketamine is realized and the explanation of ketamine effects only by changes of neuronal membrane conductive functions is not adequate.

\section{Acknowledgements}

The authors thank to Mrs. Anna Nikoghosyan for technical and editoria assistance.

\section{References}

1. Kress HG (1997) Wirkmechanismen von Ketamin. Anaesthesist 46: S8-S19.

2. Kohrs R, Durieux ME (1998) Ketamine: teaching an old drug new tricks. Anesth Analg 87: 1186-1193.

3. Davies SN, Alford ST, Coan EJ, Lester RA, Collingridge GL (1988) Ketamine blocks an NMDA receptor-mediated component of synaptic transmission in rat hippocampus in a voltage-dependent manner. Neurosci Lett 92: 213-217.

4. Reich DL, Silvay G (1989) Ketamine: an update on the first twenty-five years of clinical experience. Can J Anaesth 36: 186-197.

5. Franks NP, Lieb WR (1994) Molecular and cellular mechanisms of genera anaesthesia. Nature 367: 607-614.

6. Sakai F, Amaha K (2000) Midazolam and ketamine inhibit glutamate release via a cloned human brain glutamate transporter. Can J Anaesth 47: 800-806.

7. Franks NP (2008) General anaesthesia: from molecular targets to neurona pathways of sleep and arousal. Nat Rev Neurosci 9: 370-386.

8. Scheller M, Bufler J, Hertle I, Schneck HJ, Franke C, et al. (1996) Ketamine blocks currents through mammalian nicotinic acetylcholine receptor channels by interaction with both the open and the closed state. Anesth Analg 83: 830836.

9. Sasaki T, Andoh T, Watanabe I, Kamiya $Y$, Itoh $H$, et al (2000) Nonstereoselective inhibition of neuronal nicotinic acetylcholine receptors by ketamine isomers. Anesth Analg 91: 741-748.

10. Hustveit O, Maurset A, Oye I (1995) Interaction of the chiral forms of ketamine with opioid, phencyclidine, sigma and muscarinic receptors. Pharmacol Toxico 77: 355-359.

11. Finck AD, Ngai SH (1982) Opiate receptor mediation of ketamine analgesia Anesthesiology 56: 291-297.

12. Smith DJ, Bouchal RL, deSanctis CA, Monroe PJ, Amedro JB, et al. (1987) Properties of the interaction between ketamine and opiate binding sites in vivo and in vitro. Neuropharmacology 26: 1253-1260.

13. Schnoebel R, Wolff M, Peters SC, BrÃu ME, Scholz A, et al. (2005) Ketamine impairs excitability in superficial dorsal horn neurones by blocking sodium and voltage-gated potassium currents. Br J Pharmacol 146: 826-833.

14. Brau ME, Sander F, Vogel W, Hempelmann G (1997) Blocking mechanisms of ketamine and its enantiomers in enzymatically demyelinated peripheral nerve as revealed by single-channel experiments. Anesthesiology 86: 394-404.

15. Kawano T, Oshita S, Takahashi A, Tsutsumi Y, Tanaka K, et al. (2005) Molecular mechanisms underlying ketamine-mediated inhibition of sarcolemmal adenosine triphosphate-sensitive potassium channels. Anesthesiology 102 93-101.

16. Hirota K, Lambert DG (1996) Ketamine: its mechanism(s) of action and unusua clinical uses. Br J Anaesth 77: 441-444.

17. Akbas L, Sarioglu Y, Utkan T (1992) Effect of ketamine on contractile performance of isolated frog myocardium and comparison of ketamine thiopental and droperidol. Mater Med Pol 24: 32-34.

18. Abdalla SS, Laravuso RB, Will JA (1994) Mechanisms of the inhibitory effect 
Citation: Ayrapetyan S, Heqimyan A, Deghoyan A (2013) Cell Dehydration as a Mechanism of Ketamine Analgesic and Anesthetic Effects. J Bioequiv Availab 5: 136-141. doi:10.4172/jbb.1000148

of ketamine on guinea pig isolated main pulmonary artery. Anesth Analg 78 : $17-22$

19. Kohjitani A, Shirakawa J, Okada S, Obara H (1997) The relaxing effect of ketamine on isolated rabbit lower esophageal sphincter. Anesth Analg 84: 433437

20. Han J, Kim N, Joo H, Kim E (2003) Ketamine blocks Ca2+-activated K+ channels in rabbit cerebral arterial smooth muscle cells. Am J Physiol Heart Circ Physiol 285: H1347-1355.

21. Chang Y, Chen TL, Wu GJ, Hsiao G, Shen MY, et al. (2004) Mechanisms involved in the antiplatelet activity of ketamine in human platelets. $\mathrm{J}$ Biomed Sci 11: 764-772.

22. Ayrapetyan SN, Rychkov GY, Suleymanyan MA (1988) Effects of water flow on transmembrane ionic currents in neurons of Helix pomatia and in squid giant axons. Comp Biochem Physiol A Comp Physiol 89: 179-186.

23. Ayrapetyan SN, Arvanov VL (1979) On the mechanism of the electrogenic sodium pump dependence of membrane chemosensitivity. Comp Biochem Physiol 64: 601-604.

24. Ayrapetyan SN, Suleymanyan MA, Saghyan AA, Dadalyan SS (1984) Autoregulation of the electrogenic sodium pump. Cell Mol Neurobiol 4: 367383.

25. Ayrapetyan SN (1980) On the physiological significance of pump-induced cell volume changes. Adv Physiol Sci 23: 67-82.

26. Hoffmann EK, Lambert IH, Pedersen SF (2009) Physiology of cell volume regulation in vertebrates. Physiol Rev 89: 193-277.

27. AÄrapetian SN, Takenaka T, Bakunts IS, Sagiian AA, Dadalian SS (1986) [Membrane fluidity as a factor modulating the counter-gradient transport of sodium ions from the cell]. Dokl Akad Nauk SSSR 291: 469-472.

28. Danielian AA, Mirakian MM, AÄrapetian SN (1998) [The dehydrating action of ketamine on malignant breast tumors]. Vopr Onkol 44: 395-397.

29. Danielyan AA, Ayrapetyan SN (1999) Changes of hydration of rats' tissues after in vivo exposure to 0.2 Tesla steady magnetic field. Bioelectromagnetics 20: $123-128$.

30. TAKAHASHI R, APRISON MH (1964) ACETYLCHOLINE CONTENT OF
DISCRETE AREAS OF THE BRAIN OBTAINED BY A NEAR-FREEZING METHOD. J Neurochem 11: 887-898.

31. ADRIAN RH (1956) The effect of internal and external potassium concentration on the membrane potential of frog muscle. J Physiol 133: 631-658.

32. Ayrapetyan S, Musheghyan G, Deghoyan A (2010) The brain tissue dehydration as a mechanism of analgesic effect of hypertonic physiological solution in rats. $\mathrm{J}$ Int Dent Med Res 3: 93-9.

33. Di Lazzaro V, Oliviero A, Profice P, Pennisi MA, Pilato F, et al. (2003) Ketamine increases human motor cortex excitability to transcranial magnetic stimulation. J Physiol 547: 485-496.

34. Azatian KV, White AR, Walker RJ, Ayrapetyan SN (1998) Cellular and molecular mechanisms of nitric oxide-induced heart muscle relaxation. Gen Pharmacol 30: 543-553.

35. Saghyan A, Hunanian A, Ayrapetyan S (1997) Effect of locust poison on neuromembrane functional activity. Gen Pharmacol 29: 587-590.

36. Tasaki I, Iwasa K (1982) Rapid pressure changes and surface displacements in the squid giant axon associated with production of action potentials. Jpn J Physiol 32: 69-81.

37. Haussinger D (1996) The role of cellular hydration in the regulation of cel function. Biochem J 313: 697-710.

38. Cooke KR (1978) Ouabain and regulation of cellular volume in freshly prepared slices of rabbit renal cortex. J Physiol 279: 361-374.

39. Ayrapetyan SN, Suleymanyan M (1979) On the Pump-Induced Cell Volume Changes. Comp Biochem Physiol 64: 571-575.

40. Annunziato L, Pignataro G, Di Renzo GF (2004) Pharmacology of brain $\mathrm{Na}+/ \mathrm{Ca} 2+$ exchanger: from molecular biology to therapeutic perspectives. Pharmacol Rev 56: 633-654.

41. Saghyan AA, Dadalian SS, Takenaka T, Suleymanian MA, Ayrapetyan SN (1986) The effects of short-chain fatty acids on the neuronal membrane functions of Helix pomatia. III. 22Na efflux from the cells. Cell Mol Neurobio 6: 397-405.

42. Kandel ER, Schwartz JH (1982) Molecular biology of learning: modulation of transmitter release. Science 218: 433-443. 